\title{
Length-weight relationships for 22 crustaceans and cephalopods from the Gulf of Cadiz (SW Spain)
}

\author{
Maria Angeles Torres ${ }^{1, a,}$, Yolanda Vila ${ }^{1}$, Luis Silva ${ }^{1}$, Juan Jose Acosta ${ }^{1}$, Fernando Ramos ${ }^{1}$, \\ Maria Lourdes D. Palomares ${ }^{2}$ and Ignacio Sobrino ${ }^{1}$ \\ ${ }^{1}$ Instituto Español de Oceanografía (IEO), Centro Oceanográfico de Cádiz, Puerto Pesquero, Muelle de Levante, s/n, PO Box 2609, \\ E-11006 Cádiz, Spain \\ ${ }^{2}$ Sea Around Us Project, Institute for the Oceans and Fisheries, University of British Columbia, 2202 Main Mall, Vancouver, \\ B.C. V6T 1Z4, Canada \\ ${ }^{a}$ Current address: Centre of Marine Sciences (CCMAR), University of the Algarve, Campus de Gambelas, Faro 8005-139, Portugal
}

Received 19 July 2016 / Accepted 6 March 2017

\begin{abstract}
Life history traits are available for many fish species in different regions, but less so for invertebrates such as cephalopods and crustaceans, though, they are increasingly needed for implementing an ecosystem-based approach. Recent food web modelling in the Gulf of Cadiz has identified invertebrates as keystone groups. However, information on life history traits of such groups remains incomplete in this region. To fill this knowledge gap, we report length-weight relationships for 12 cephalopods and 10 crustaceans collected in the Gulf of Cadiz from 2009 to 2013. This study reports, for the first time, life history traits of nine species in the area (Chlorotocus crassicornis, Pasiphaea sivado, Plesionika heterocarpus, Plesionika martia, Processa canaliculata, Solenocera membranacea, Allotheutis media, Sepia orbignyana and Sepietta oweniana). For each species, length-weight relationships, minimum and maximum lengths, mean weights, and depth ranges are presented. Overall, the results revealed that all species showed negative allometric growth (hypoallometry), except $P$. sivado, the only species showing an isometric growth pattern. We expect that this study will contribute to link sustainable fisheries with biodiversity conservation goals enabling the implementation of operational ecosystem-based management in the Gulf of Cadiz.
\end{abstract}

Keywords: Maximum length / Growth pattern / Invertebrates / Trophic resources / Distribution range / Ecosystembased management

\section{Introduction}

Body length-weight relationships of marine populations provide useful information for fishery management (Pauly, 1984). For instance, length-weight relationships allow calculating condition indices, analyzing ontogenetic changes and are needed as input to stock assessment models. Parameters of length-weight relationships are available for most fish species in FishBase (www.fishbase.org), a global information system on fish (Froese and Pauly, 2016). However, they are not as readily available for benthic and benthopelagic invertebrate organisms such as cephalopods and crustaceans; though, some are available via SeaLifeBase (www.sealifebase. org), a global information system on marine organisms other

\footnotetext{
* Corresponding author: matorres@ualg.pt, torresleal.ma@gmail.com
}

than fish, which follows the successful FishBase model (Palomares and Bailly, 2011; Palomares and Pauly, 2016).

Currently, 'non-fish' groups are gaining importance to implement ecosystem-based management approaches in marine systems (Garcia et al., 2003). Furthermore, information on length-weight relationships of the target species is also required to achieve the goals of the European Marine Strategy Framework Directive (2008/56/EC). In general, this integrated approach takes into consideration both commercial species and non-commercial species which play key ecological roles in the ecosystem. Therefore, data regarding these organisms are greatly needed to have a better understanding of the functioning of any marine ecosystem (Palomares and Pauly, 2008).

The Gulf of Cadiz marine ecosystem (ICES Subdivision IXa, South), is characterized by high biodiversity, productivity, and socio-economic importance (Sobrino et al., 1994; Ramos et al., 2012). It extends $303 \mathrm{~km}$ along the Atlantic coastline (Sobrino et al., 1994), where fishing has been identified as one of the major human-induced threats to marine biodiversity 


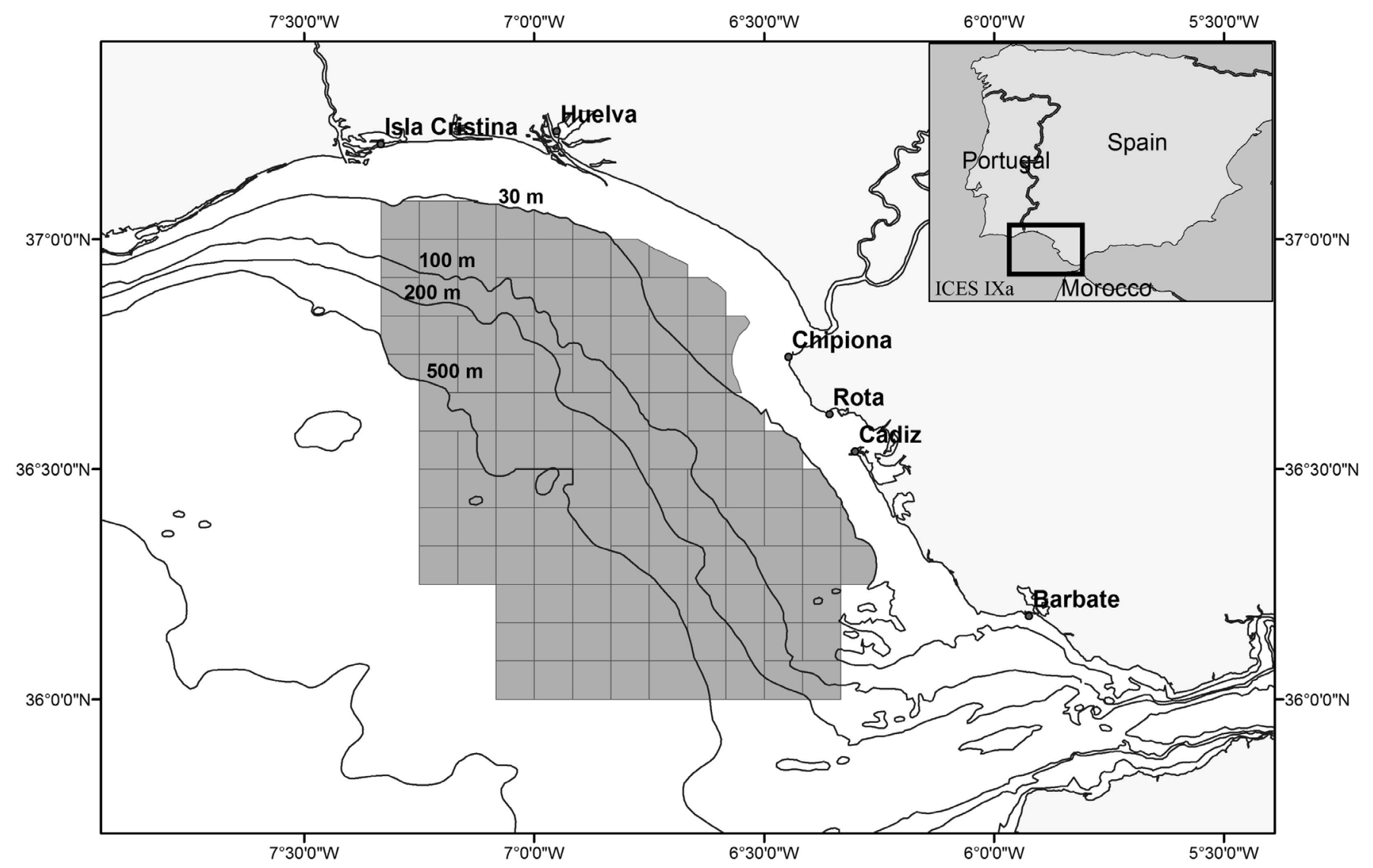

Fig. 1. The study area: Gulf of Cadiz (ICES Subdivision IXa South, Spain). The shadowed area comprises the surveyed area where the specimens were collected.

(Torres et al., 2013). Many invertebrates are commercially exploited in this area (Sobrino et al., 1994). For these species, fishing and biological traits have been widely described, e.g. Octopus vulgaris (Silva et al., 2002; Sobrino et al., 2011), Sepia officinalis (Tirado et al., 2003), Eledone moschata (Silva et al., 2004), Loligo vulgaris (Vila et al., 2010), Parapenaeus longirostris (Sobrino et al., 2005) and Squilla mantis (Vila et al., 2013). However, an update of local length-weight relationships of these species is needed since they vary over time and geographically (Merella et al., 1997; Guijarro et al., 2012).

Recent studies, performed to implement an ecosystembased approach in the Gulf of Cadiz, have identified several non-commercial cephalopod species (e.g. Sepietta oweniana) and crustaceans (e.g. Pasiphaea sivado, Processa canaliculata, Chlorotocus crassicornis and Solenocera membranacea) as key species within the Gulf of Cadiz food web (Torres et al., 2013). These species are important trophic resources for sharks, skates, grenadiers, and the European hake Merluccius merluccius during its early life stages (Torres and Sobrino, 2012; Torres, 2013). Unfortunately, to the best of our knowledge, information of their life history traits remains scarce in the study area.

This paper reports length-weight relationships, minimum and maximum lengths, mean weights, and bathymetric distribution ranges of 22 invertebrate species belonging to
Cephalopoda (12) and Decapoda (10) common in the Gulf of Cadiz. Furthermore, this study presents the first morphometric relationships for the study area of the following species: $C$. crassicornis, P. sivado, Plesionika heterocarpus, Plesionika martia, P. canaliculata, S. membranacea, Allotheutis media, Sepia orbignyana and $S$. oweniana.

\section{Methods}

\subsection{Sampling strategy}

The specimens for the selected 22 species were gathered and measured during the bottom trawl surveys (Arrastre Región Sur-Atlántica, ARSA) carried out in the Gulf of Cadiz waters during the period 2009-2013. These surveys are undertaken twice a year (spring and autumn) following a stratified random sampling design with hauls ranging from 15 to $800 \mathrm{~m}$ (Fig. 1). All species presented a high variability in length and overlapping length ranges for the two sampling seasons.

For the commercial cephalopods S. officinalis and Sepia elegans, and crustaceans $P$. longirostris and $S$. mantis, samples from commercial landings taken monthly throughout the same sampling period were also used in this study (IEO, Database). Hence, these species presented the highest sample sizes. The list of the selected species as well as the sample sizes are shown in Table 1 (crustaceans) and Table 2 (cephalopods). 
Table 1. Parameter estimates of the length-weight relationship for the selected crustacean species in the Gulf of Cadiz: $N$ (sample size), $a$ intercept (CV by bootstrap), $b$ slope (CV by bootstrap) and $R$ coefficient of determination. Lengths are presented for cephalothorax (cm): $L_{\text {min }}$ minimum observed length, $L_{\max }$ maximum observed length and mean length (SD), and weights are mean wet weights in $g(\mathrm{SD})$. Depth range (m) is also shown for each species in the study area.

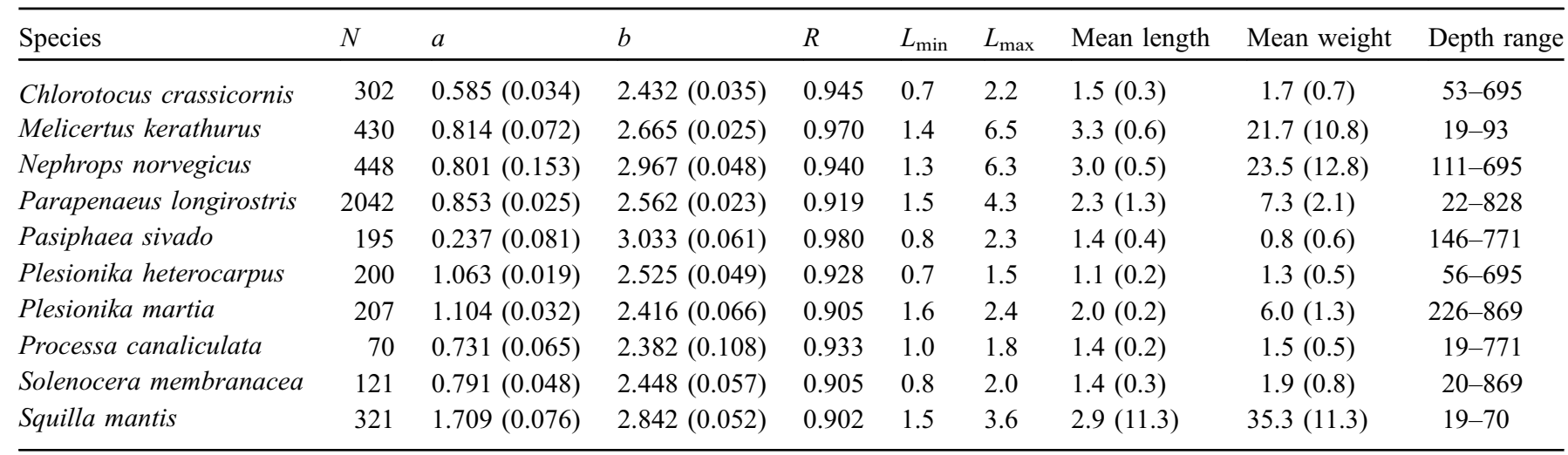

Table 2. Parameter estimates of the length-weight relationship for the selected cephalopod species in the Gulf of Cadiz: $N$ (sample size), $a$ intercept ( $\mathrm{CV}$ by bootstrap), $b$ slope ( $\mathrm{CV}$ by bootstrap) and $R$ coefficient of determination. Lengths are presented for dorsal mantle length (cm): $L_{\min }$ minimum observed length, $L_{\max }$ maximum observed length and mean length (SD), and weights are mean wet weights in $g$ (SD). Depth range $(\mathrm{m})$ is also shown for each species in the study area.

\begin{tabular}{|c|c|c|c|c|c|c|c|c|c|}
\hline Species & $N$ & $a$ & $b$ & $R$ & $L_{\min }$ & $L_{\max }$ & Mean length & Mean weight & Depth range \\
\hline Eledone cirrhosa & 100 & $1.056(0.254)$ & $2.341(0.045)$ & 0.951 & 3.5 & 15.0 & $6.1(1.6)$ & $81.5(52.9)$ & $35-108$ \\
\hline Illex coindetii & 232 & $0.043(0.252)$ & $2.913(0.032)$ & 0.943 & 4.8 & 25.0 & $13.4(3.5)$ & $96.6(64.2)$ & $44-695$ \\
\hline Loligo forbesi & 390 & $0.111(0.104)$ & $2.553(0.014)$ & 0.980 & 6.0 & 29.4 & $14.2(4.2)$ & $114.6(87.2)$ & $68-431$ \\
\hline Sepia elegans & 2672 & $0.229(0.074)$ & $2.577(0.021)$ & 0.947 & 1.6 & 7.4 & $4.0(0.8)$ & $9.0(4.6)$ & $16-447$ \\
\hline Sepia officinalis & 1839 & $0.212(0.121)$ & $2.802(0.015)$ & 0.990 & 2.5 & 29.6 & $11.7(3.6)$ & $260.2(259.4)$ & $19-242$ \\
\hline Sepia orbignyana & 69 & $0.394(0.222)$ & $2.380(0.046)$ & 0.921 & 2.8 & 8.8 & $6.7(1.3)$ & $38.6(17.4)$ & $24-494$ \\
\hline Sepietta oweniana & 80 & $0.653(0.107)$ & $2.070(0.071)$ & 0.946 & 0.5 & 3.6 & $1.9(0.6)$ & $2.8(1.8)$ & $42-701$ \\
\hline Todaropsis eblanae & 157 & $0.182(0.149)$ & $2.668(0.023)$ & 0.977 & 3.5 & 23.0 & $9.1(3.0)$ & $83.2(70.2)$ & $42-686$ \\
\hline
\end{tabular}

Cephalopod length (dorsal mantle length; DML) was measured to the nearest $0.1 \mathrm{~cm}$ using a measurement board. Crustacean length was measured to the nearest $0.01 \mathrm{~mm}$ from the orbit of the eye to the posterior border of the cephalothorax (carapace length; CL) using a digital caliper. Note that for $S$. mantis, CL was measured from the median posterior edge of the carapace to the base of the rostrum following Vila et al. (2013). All specimens were weighed to the nearest $0.01 \mathrm{~g}$ using a digital balance (wet body weight, $W$ ).

\subsection{Statistical analyses}

Length-weight relationships were determined, as previously applied for fish species in the study area (Torres et al., 2012), using the classical equation (Eq. (1)):

$$
W=a L^{b}
$$

where $W$ is wet body weight, $L$ is length (DML or CL), $a$ is the intercept of the regression curve and $b$, the scaling exponent (Ricker, 1973). Parameters $a$ and $b$ were estimated for both sexed pooled using linear least-squares for log-transformed data.

The pattern of growth, i.e. negative allometry $(b<3)$, isometry $(b=3)$ or positive allometry $(b>3)$, was tested using regression analyses (ANOVA) and setting a significance level of 0.05 . The relationships among length and weight were estimated with INBIO R package (Sampedro et al., 2005), which uses non-parametric bootstrapping (1000 replicates) to estimate the coefficient of variation for both parameters $a$ and $b$ for each species. 


\section{Results and discussion}

A total of 13,718 specimens belonging to 22 species (12 families) of crustaceans and cephalopods were analyzed in this study. Sample size varied between species as some were difficult to catch by the trawling gear due to their small body size (e.g. P. canaliculata and S. oweniana), their low abundance (e.g. S. orbygniana) or problems with identification (A. media). Despite these limitations, the present study provides the first compilation of their morphometric relationships in the area.

The coefficient of determination $R$ for length-weight relationships ranged between 0.90 for $S$. mantis and 0.99 for S. officinalis indicating good fits $(p<0.05)$ (Tables 1 and 2$)$. Scaling exponents $(b)$ varied between species. The mesopelagic decapod P. sivado had the largest coefficient $(b=3.03)$, considerably different from the rest of the species analysed $(p<0.05)$, but similar to the findings obtained for females in the north-western Mediterranean Sea (Cartes and Sardà, 2001). Conversely, the smallest coefficient was found for the sepiolid S. oweniana (2.07). In terms of type of growth, scaling exponents $b$ were significantly smaller than 3, indicating a negative allometric (hypoallometry) growth pattern for all species except for the deep-water shrimp $P$. sivado. In general, our results suggest that size (i.e. growth) was not proportional to weight, in accordance with the findings reported in other Atlantic (Rodríguez-Marín, 1993; Regueira et al., 2013) and Mediterranean marine systems (Merella et al., 1997; Conides et al., 2006; Vafidis et al., 2008; Guijarro et al., 2012; Dursun et al., 2013). Allometric growth patterns are common in short-lived species such as cephalopods, for example O. vulgaris (Merella et al., 1997; Quetglas et al., 1998) or Loligo fobersi (Pierce et al., 1994), but also in deep-water pandalids (Vafidis et al., 2008), possibly as an adaptation to changes in benthic habitats (Company and Sardà, 2000).

Scaling exponents $b$ different from 3.0 (e.g. S. oweniana and $A$. media) were often associated with narrow length ranges of the specimens examined (Table 2), but the overall relationship between $b$ and length range was not significant. Hence, these length-weight relationships should be taken only for the respective length ranges considered in this study. Finally, the bootstrap analyses revealed that both $a$ and $b$ were precisely estimated $(p<0.05)$, except for the crustaceans shown in Table $1(p>0.05)$, possibly associated with a scarce representation of small-sized individuals in the sample.

Most selected species showed wide bathymetric distribution ranges overlapping between species, although they are restricted to certain depth ranges (see Tables 1 and 2). In the study area, the deepest depths were reached by the crustaceans P. longirostris ( $828 \mathrm{~m})$, P. martia $(869 \mathrm{~m})$, and S. membranacea $(869 \mathrm{~m})$. At these depths, such decapods constitute important trophic resources for the deep-sea fishes (Torres, 2013). In contrast, the penaeid M. kerathurus inhabits shallower waters reaching high abundances near the Guadalquivir river estuary (Silva et al., 2003). Cephalopods also presented wide bathymetric distribution ranges, showing the maximum depths S. oweniana $(705 \mathrm{~m})$, Illex coindetii $(695 \mathrm{~m})$, and Todaropsis eblanae $(686 \mathrm{~m})$. A detailed description of the cephalopod and crustacean assemblages and bathymetric distribution over time and space in the Gulf of Cadiz can be found in Acosta (2010) and Silva et al. (2011).

Despite the new insights described in this study, the growth pattern of most species selected might vary temporally and spatially according to factors such as temperature, salinity, depth, food availability, reproductive activity, size, sex and season (Pauly, 1984; Safran, 1992; Belcari, 1996; Froese, 2006; Vafidis et al., 2008; Guijarro et al., 2012). In addition, morphometric relationships might also have been affected by sampling characteristics (e.g. fishing gear, measuring equipment or number of individuals sampled). It is well known that life-history strategies of short-lived species may be highly flexible in response to changing environmental conditions (Guijarro et al., 2012; Lourenco et al., 2012) but also to humaninduced stressors. For example, fishing seems to assume an important role in regulating the size structure in these populations (Barry and Tegner, 1990; Maiorano et al., 2002). In the Gulf of Cadiz, benthic cephalopods such as $O$. vulgaris and $S$. officinalis are influenced by both global climatic indices and local drivers such as temperature, productivity and rainfalls (Sobrino et al., 2002). None of these factors were considered in the present study. Despite the low number of samples for some species, and the lack of environmental variables considered in the analyses, the results presented here contribute to the basic knowledge needed for sustainable fisheries and biodiversity conservation goals in the frame of a desired future ecosystem-based approach in the Gulf of Cadiz.

Acknowledgments. The authors would like to thank the scientific and technical staff of the IEO who helped us to collect all data used in this study, especially to Teresa García and Ana Juárez. We also thank the IEO for the financial support to M.A. Torres through a Predoctoral FPI Fellowship.

\section{References}

Acosta JJ. 2010. Asociaciones de crustáceos en el Golfo de Cádiz y variables ambientales relacionadas, MSc thesis. University of Cadiz, $59 \mathrm{p}$

Barry JP, Tegner MJ. 1990. Inferring demographic processes from size-frequency distributions: simple models indicate specific patterns of growth and mortality. Fish Bull 88: 13-19.

Belcari P. 1996. Length-weight relationships in relation to sexual maturation of Illex coindetii (Cephalopoda: Ommastrephidae) in the northern Tyrrhenian Sea (Western Mediterranean). Sci Mar 60 (2-3): 379-384.

Cartes J, Sardà F. 2001. Biological patterns and near-bottom population characteristics of two pasiphaeid decapod crustacean species, Pasiphaea sivado and P. multidentata, in the northwestern Mediterranean Sea. Mar Biol 139 (1), 61-73.

Company JB, Sardà F. 2000. Growth parameters of deep-water decapod crustaceans in the northwestern Mediterranean Sea: a comparative approach. Mar Biol 136: 79-90.

Conides A, Glamuzina B, Jug-Dujakovic J, Papaconstantinou C, Kapiris K. 2006. Age, growth, and mortality of the karamote shrimp, Melicertus kerathurus (Forskål, 1775), in the east Ionian Sea (Western Greece). Crustaceana 79 (1): 33-52. 
Dursun D, Eronat EGT, Akalin M, Salman MA. 2013. Reproductive biology of pink cuttlefish Sepia orbignyana in the Aegean Sea (eastern Mediterranean). Turk J Zool 37 (5): 576-581.

Froese R. 2006. Cube law, condition factor and weight-length relationships: history, meta-analysis and recommendations. $J \mathrm{Appl}$ Ichthyol 22: 241-253.

Froese F, Pauly D, eds. 2016. FishBase. World Wide Web electronic publication. Available from: www.fishbase.org (last consulted on: 2016/06).

Garcia SM, Zerbi A, Aliaume C, Do Chi T, Lasserre G. 2003. The ecosystem approach to fisheries. Issues, terminology, principles, institutional foundations, implementation and outlook. FAO Fisheries Technical Paper. No. 443. Rome: FAO, 71 p.

Guijarro B, Fanelli E, Moranta J, Cartes JE, Massutí E. 2012. Smallscale differences in the distribution and population dynamics of pandalid shrimps in the western Mediterranean in relation to environmental factors. Fish Res 119: 33-47.

Lourenco S, Moreno A, Narciso L, Gonzalez AF, Pereira J. 2012. Seasonal trends of the reproductive cycle of Octopus vulgaris in two environmentally distinct coastal areas. Fish Res 127: 116124.

Maiorano P, D’Onghia G, Capezzuto F, Sion L. 2002. Life-history traits of Plesionika martia (Decapoda: Caridea) from the easterncentral Mediterranean Sea. Mar Biol 141 (3): 527-539.

Merella P, Quetglas A, Alemany F, Carbonell A. 1997. Length-weight relationship of fishes and cephalopods from the Balearic Islands (western Mediterranean). Naga ICLARM Q 20: 66-68.

Palomares MLD, Bailly N. 2011. Organizing and disseminating marine biodiversity information: the FishBase and SeaLifeBase story. In: Christensen V, Maclean J. eds. Ecosystem approaches to fisheries. A global perspective. New York: Cambridge University Press, pp. 24-46.

Palomares MLD, Pauly D. 2008. Von Bertalanffy growth parameters of non-fish marine organisms. Fisheries Centre Research Reports $16,140 \mathrm{p}$.

Palomares MLD, Pauly D, eds. 2016. SeaLifeBase. World Wide Web electronic publication. Available from: www.sealifebase.org (last consulted on: 2016/06).

Pauly D. 1984. Fish population dynamics in tropical waters: a manual for use with programmable calculators. ICLARM Stud Rev 8: 325.

Pierce GJ, Boyle PR, Hastie LC, Key L. 1994. The life history of Loligo forbesi (Cephalopoda: Loliginidae) in Scottish waters. Fish Res 21: 17-41.

Quetglas A, Alemany F, Carbonell A, Merella P, Sánchez P. 1998. Biology and fishery of Octopus vulgaris Cuvier, 1797, caught by trawlers in Mallorca (Balearic Sea, Western Mediterranean). Fish Res 36: 237-249.

Ramos F, Gil J, Torres MA, Silva L, Vila Y, Sánchez R, et al. 2012. Estrategias Marinas. Demarcación Marina Sudatlántica. Parte I. Marco General: características de la demarcación marina. Madrid: Ministerio de Agricultura, Alimentación y Medio Ambiente (MAGRAMA), Instituto Español de Oceanografía (IEO), Centro de Estudios de Puertos y Costas-Centro de Estudios y Experimentación de Obras Públicas (CEPYC-CEDEX), 127 pp. Available from: http://www.magrama.gob.es/es/costas/temas/pro teccion-medio-marino/I_Marco_General_Sudatlanti ca tcm7-203272.pdf.

Regueira M, González AF, Guerra Á, Soares A. 2013. Reproductive traits of horned octopus Eledone cirrhosa in Atlantic Iberian waters. J Mar Biol Assoc UK 93: 1641-1652.

Ricker WE. 1973. Linear regressions in fishery research. J Fish Res Board Can 30: 409-434.
Rodríguez-Marín E. 1993. Biometry of decapod crustaceans in the Cantabrian Sea. Crustaceana 65 (2): 192-203.

Safran P. 1992. Theoretical analysis of the weight-length relationships in the juveniles. Mar Biol 112: 545-551.

Sampedro P, Saínza M, Trujillo V. 2005. A simple tool to calculate biological parameters' uncertainty. Working document in workshop on sampling design for fisheries data.

Silva L, Sobrino I, Ramos F. 2002. Reproductive biology of the common octopus, Octopus vulgaris Cuvier, 1797 (Cephalopoda: Octopodidae) in the Gulf of Cádiz (SW Spain). Bull Mar Sci 71: 837-850.

Silva L, García-Isarch E, Sobrino I, García A. 2003. Distribución espacio-temporal del langostino Melicertus kerathurus (Forsköl, 1775) en la desembocadura del río Guadalquivir (Golfo de Cádiz, suroeste de la península Ibérica). Bol Inst Esp Oceanogr 19: 4147.

Silva L, Ramos F, Sobrino I. 2004. Reproductive biology of Eledone moschata (Cephalopoda: Octopodidae) in the Gulf of Cadiz (south-western Spain, ICES Division IXa). J Mar Biol Assoc UK 84: $1221-1226$

Silva L, Vila Y, Torres MA, Sobrino I, Acosta JJ. 2011. Cephalopod assemblages, abundance and species distribution in the Gulf of Cadiz (SW Spain). Aquat Living Resour 24: 13-26.

Sobrino I, Jiménez MP, Ramos F, Baro J. 1994. Descripción de las pesquerías demersales de la región suratlántica española. Bol Inst Esp Oceanogr 151: 76 + 72 Anexos.

Sobrino I, Silva L, Bellido JM, Ramos F. 2002. Rainfall, river discharges and sea temperature as factors affecting abundance of two coastal benthic cephalopod species in the Gulf of Cádiz (SW Spain). Bull Mar Sci 71: 851-865.

Sobrino I, Silva C, Sbrana M, Kapiris K. 2005. A review of the biology and fisheries of the deep water rose shrimp, Parapenaeus longirostris, in European Atlantic and Mediterranean waters (Decapoda, Dendrobranchiata, Penaeidae). Crustaceana 78: 1153-1184.

Sobrino I, Juarez A, Rey J, Romero Z, Baro J. 2011. Description of the clay pot fishery in the Gulf of Cadiz (SW Spain) for Octopus vulgaris: selectivity and exploitation pattern. Fish Res 108: 283290.

Tirado C, Rodríguez de la Rúa A, Bruzón MA, López JI, Márquez I. 2003. La reproducción del pulpo (Octopus vulgaris) y el choco (Sepia officinalis) en la costa andaluza. In: Consejería de Agricultura y Pesca, ed. Sevilla: Junta de Andalucía, 129 p.

Torres MA. 2013. Modelización ecológica del Golfo de Cádiz: relaciones tróficas, análisis de la estructura de la comunidad e impacto de la pesca en el ecosistema, $\mathrm{PhD}$ dissertation. University of Cadiz. Available from: http://rodin.uca.es/xmlui/handle/10498/ 15891.

Torres MA, Sobrino I. 2012. Feeding habits of European hake Merluccius merluccius(L. 1758) in the Gulf of Cadiz. In: Final Proceedings in International Symposium of the Marine Science (ISMS), Cádiz, Spain.

Torres MA, Ramos F, Sobrino I. 2012. Length-weight relationships of 76 fish species from the Gulf of Cadiz (SW Spain). Fish Res $127-$ 128: 171-175.

Torres MA, Coll M, Heymans JJ, Christensen V, Sobrino I. 2013. Food-web structure of and fishing impacts on the Gulf of Cadiz ecosystem (South-western Spain). Ecol Model 265: 26-44.

Vafidis D, Leontarakis PK, Dailianis T, Kallianiotis A. 2008. Population characteristics of four deep-water pandalid shrimps (Decapoda: Caridea) in the northern Aegean Sea (NE Mediterranean). J Nat Hist 42 (31-32): 2079-2093. 
Vila Y, Silva L, Torres MA, Sobrino I. 2010. Fishery, distribution pattern and biological aspects of the common European squid Loligo vulgaris in the Gulf of Cadiz. Fish Res 106: 222-228.
Vila Y, Sobrino I, Jiménez MP. 2013. Fishery and life history of spottail mantis shrimp, Squilla mantis (Crustacea: Stomatopoda), in the Gulf of Cadiz (eastern central Atlantic). Sci Mar 77: 137-148.

Cite this article as: Torres MA, Vila Y, Silva L, Acosta JJ, Ramos F, Palomares MLD, Sobrino I. 2017. Length-weight relationships for 22 crustaceans and cephalopods from the Gulf of Cadiz (SW Spain). Aquat. Living Resour. 30: 12 